\title{
EVALUASI PROGRAM JAMINAN PERSALINAN (JAMPERSAL) DI PUSKESMAS PELITAKAN KABUPATEN POLEWALI MANDAR.
}

\author{
Darmawin $^{1,}$ Muhlis Madani ${ }^{2}$, Nuryanti Mustari ${ }^{3}$ \\ ${ }^{1)}$ Program Studi Ilmu Administrasi Negara Unismuh Makassar \\ ${ }^{2)}$ Program Studi Ilmu Administrasi Negara Unismuh Makassar \\ ${ }^{3)}$ Program Studi Ilmu Administrasi Negara Unismuh Makassar
}

\begin{abstract}
The research aimed to measure capability of government and the agency related, how did people satisfy, the exactness objective Birth Assurance (Jampersal) program, and public service was received by society. This research used qualitative research through 8 informants. The data collection were deep interview, direct observation and documentation. This research showed the principal case in Jampersal was improvement the quality access of birth, the role government also can give more influence in this program, increasing the human resource for realization that policy, especially they can work professionally in public service.
\end{abstract}

Kewords : Evaluation, Birth Assurance (Jampersal).

\begin{abstract}
ABSTRAK
Penelitian ini bertujuan untuk melakukan pengukuran kinerja pemerintah dan aparat yang terkait. kepuasan masyarakat dan ketepatan sasaran program jaminan persalinan serta pelayanan publik yang diterima oleh masyarakat. Penelitian ini mengunakan tipe penelitian kualitatif dengan informan sebanyak 8 orang. Teknik pengumpulan data dengan wawancara mendalam, observasi langsung, dokumentasi. Hasil penelitian ini menunjukkan bahwa hal yang sangat pokok dalam kebijakan jaminan persalinan adalah pembenahan akses kualitas pelayanan persalinan. Peran pemerintah juga berpengaruh besar dalam program ini, peningkatan sumber daya manusia yang mempuni untuk mensukseskan kebijakan tersebut, terutama dalam sumber daya manusia yang dapat bekerja dengan profesionalitas dalam melakukan pelayanan publik.
\end{abstract}

Kata kunci: Evaluasi, Program Jaminan Persalinan (Jampersal). 


\section{PENDAHULUAN}

Tujuan Jampersal adalah untuk mencapai pembangunan millennium yang meningkatkan kesehatan keluarga dimana target yang akan dicapai sampai tahun 2020 adalah mengurangi sampai $3 / 4$ resiko jumlah kematian ibu dan bayi.

hasil survey yang dilakukan oleh Angka Kematian Ibu telah menunjukkan penurunan dari waktu kewaktu sejak dilaksanakanya program jaminan persalinan. Berbagai macam kegiatan dari hasil musrembang desa, kecamatan dan kabupaten (forum SKPD dan Musrembang Kabupaten) dengan skala prioritas terhimpun dalam pembangunan kesehatan tahun 2016 adalah status derajat kesehatan masyarakat sebagai salah satu indikator Indeks Kualitas Sumber Daya Manusia yaitu angka harapan hidup. ( umur panjang dan sehat) yang sulit ditingkatkan karena adanya angka kematian ibu dan bayi skala kabupaten yang masih sangat tinggi.

Menurut hasil riskesdes, 2010 persalinan oleh kelompok tenagan kesehatan pada kelompok sasaran miskin (Quintile 1) baru mencapai sekitar 60,3\%. Sedangkan persalinan yang dilakukan oleh tenaga kesehatan difasilitas tenaga kesehatan baru mencapai $55,4 \%$ salah satu kendala penting untuk mengakses persalinan oleh tenaga kesehatan difasilitas kesehatan adalah keterbatasan dan ketidak sediaan biaya sehingga diperlukan kebijakan dan terobosan untuk meningkatkan persalinan yang ditolong oleh tenaga kesehatan dan difasilitasi oleh pemerintah.

Jaminan persalinan bertujuan menghilankan hambatan finansial bagi ibu hamil dan bayi baru lahir, tidak hanya AKI yang hendak diturunkan dengan jampersal juga AKB sehingga target pemerintah untuk meningkatkan derajat kesehatan masyarakat dapat tercapai dan target MDG's juga diharapkan tercapai dengan berbagai program kegiatan yang dilaksanakan. ditahun 2014 kematian ibu berada dalam angka on the track yaitu 5 kematian ibu dalam setahun kembali naik 17 kematian ibu ditahun 2015. Salah satu penyebabnya adalah kurang 
pemahaman masyarakat terhadap program jampersal.

Dari kementrian kesehatan RI yang menjamin semua ibu kaya ataupun miskin ditangun oleh Negara alias digratiskan, program jampersal ini juga berdampak pada masih tinginya angka kematian bayi ditahun 2015 yaitu dari 8336 kelahiran hidup masih ditemukan 109 kematian bayi.

Kebijakan adalah sebuah ketetapan yang berlaku yang dicirikan dan mencirikan oleh prilaku yang konsisten dan berulang baik dari yang membuatnya maupun yang taat pada kebijakan tersebut yang merupakan prinsip yang mengatur tindakan yang diarahkan kepada tujuan-tujuan tertentu yang dimana kebijakan itu selalu beriorientasi kepada masalah (problem-oriented) dan beriorientasi pada tindakan (action-oriented)

Permasalahan yang lain yang terjadi adalah masih kuranya sarana dan prasarana kesehatan diberbagai tempat seperti puskesmas dan kurangnya respon tenaga kesehatan seperti bidan desa, bidan kecamatan terhadap masyarakat atau ibu hamil terpaksa tidak mematuhi aturan tersebut jika keadaan harus melahirkan dirumah masyarakat dibebangkan untuk menangu biaya pelangaran yang dalam hitungan sangat tinggi dikalangan masyarakat ekonomi kebawah.

Tujuan pokok evaluasi adalah untuk melihat seberapa besar kesenjangan antara pencapaian dan harapan suatu kebijakan pablik selanjutmya adalah bagaimana mengurangi atau menutup kesenjangan tersebut. Evaluasi bertujuan untuk mencari kekurangan dan menutup kekurangan.

Evaluasi kebijakan pablik menurut Nugroho (2009) adalah bertujuan untuk membentuk hal-hal yang strategis untuk meningkatkan kinerja kebijakan, evaluator mampu mengambil jarak dari pembuat kebijakan pelaksanaan kebijakan dan target kebijakan, prosedur dapat bertangun jawab secara metodeologi dan dilaksanakan tidak dalam permusuhan atau kebencian, mencakup rumusan implementasi, linkungan dan kinerja kebijakan.

Evaluasi kebijakan pablik merupakan suatu aktifitas yang 
dirangcan untuk menilai hasil-hasil kebijakan pemerintah yang mempunyai perbedaan yang sangat penting dalam spesifikasi objeknya teknik-teknik pengukurannya dan metode analisisnya (Subarsono 2005).

Evaluasi adalah kegiatan
untuk mengumpulkan informasi
tentang bekerjanya sesuatu yang
selanjutnya informasi tersebut
digunakan untuk menentukan
alternatif yang tepat dalam
mengambil suatu keputusan
(Arikunto dan Cepi 2008).

Evaluasi adalah suatu proses yang ditempuh seseorang untuk memperoleh informasi yang berguna untuk menentukan mana dari dua hal merupakan alternatif yang dinginkan karena penentu atau keputusan semacam ini tidak diambil secara acak, maka alternatif itu harus dinilai secara relatif karena pemberian nilai itu harus melalui pertimbangan yang rasional berdasarkan informasi untuk proses pengambilan keputusan (Uzer 2003).

Menurut Arikunto (2002) ada dua tujuan evaluasi yaitu tujuan umum dan tujuan khusus tujuan umum diarahkan pada program secara keseluruhan, sedangkan tujuan khusus lebih difokuskan pada masing-masing komponen.

Evaluasi menurut Crawford (2002) tujuan dan fungsi evaluasi adalah untuk mengetahui apakah tujuan-tujuan yang telah ditetapkan telah tercapai dalam kegiatan untuk memberikan objektifitas pengamatan terhadap perilaku hasil mengetahui kemampuan dan menentukan kelayakan dalam memberikan umpan balik bagi kegiatan yang dilakukan.

Menurut Dunn

(2003) evaluasi mempunyai sejumlah karakteristik yang membedakan dari metode-metode analisis kebijakan lainnya: (a) Fokus Nilai evaluasi dipusatkan pada penilaian menyankut keperluan atau nilai dari suatu kebijakan dan program, evaluasi terutama untuk menentukan manfaat atau kegunaan sosial kebijakan atau program dan bukan sekedar usaha mengumpulkan informasi mengenai hasil aksi kebijakan yang transparansi dan tidak transparansi. interdependansi fakta nilai tuntutan evaluasi tergantun baik "fakta" 
maupun "nilai" untuk menyatakan bahwa kebijakan atau program tertentu telah mencapai tingkat kinerja yang tertinggi diperlukan tidak hanya bahwa hasil kebijakan secara aktual merupakan konsekuensi dari aksi yang dilakukan untuk memecahkan masalah tertentu oleh karena itu pemantauan merupakan prasyarat bagi evaluasi. (c) orientasi masa kini dan masa lampau.

Tuntutan evaluasi berada dengan tututan abvokatif diarahkan pada hasil sekarang dan masa lalu, ketimbang hasil di masa depan evaluasi bersifat retrospektif juga mencakup premis-premis nilai, bersifat prospektif dan dibuat sebelum aksi-aksi dilakukan (exante). (d) Dualitas nilai.

Nilai-nilai yang mendasari tuntutan evalauasi mempunyai kualitas ganda karena mereka dipandan sebagai tujuan dan sekaligus cara evaluasi sama dengan rekomendasi yang berkenaan dengan nilai yang ada dapat diangap sebagai intruistic atau pun ekstriktik, nilainilai yang sering ditata didalam suatu hierarki yang merefleksikan kepentingan relative dan saling ketergantungan antar tujuan dan sasaran.

Menurut Stufflebeam dalam lababa (2008) evaluasi adalah merupakan proses mengambarkan, memperoleh dan menyajikan informasi yang berguna untuk merumuskan suatu alternative kepuasan.

Worthen dan Sanders (2008) mendefenisikan evaluasi sebagai usaha untuk mencari sesuatu yang berharga yang dapat berupa informasi tentan suatu program dan produksi serta alternative prosedur tertentu, evaluasi bukan sekedar menilai suatu aktifitas secara spontan dan insidental, melainkan merupakan kegiatan untuk menilai suatu secara terencana, sistematik dan terarah berdasarkan tujuan yang jelas.

Menurut Zaenal Mukarom dan Muhibudin Wijaya Laksana (2015) monitorin evaluasi adalah suatu proses untuk mengetahui pelaksanaan program yang sedan berjalan, kegiatan monitoring dapat membantu meningkatkan kualitas program dan mengidentifikasi 
masalah-masalah yang harus diatasi untuk mencapai program.

Terobosan pemerintah yang memberikan kebijakan kesehatan khususnya pemberdayaan perempuan dan penekanan kematian AKI dan AKB kebijakan jampersal yang telah dikeluarkan oleh kementrian kesehatan mempunyai dasar hukum yang bersifat operasional sebagai berikut: peraturan menteri kesehatan RI Nomor 210 /Menkes/Per/I/2011.

Tentang petunjuk tehnis bantuan operasional kesehatan tahun 2011. Peraturan menteri kesehatan RI Nomor 631/Menkes/ Per/III/2011 Tentang Petunjuk Tehnis Jaminan Persalinan.

Undang-Undang Nomor 23 Tahun 2014 tentang Pemerintahan Daerah, pada Pasal 298 ayat (7) menyebutkan belanja DAK diprioritaskan untuk mendanai kegiatan fisik dan dapat digunakan untuk kegiatan nonfisik. Tahun 2017 Pemerintah mengalokasikan anggaran DAK Bidang Kesehatan sebesar Rp.23.220.985.381.000,(dua puluh tiga triliun dua ratus dua 9 puluh miliar sembilan ratus delapan puluh lima juta tiga ratus delapan puluh satu ribu rupiah) terdiri dari DAK Fisik sebesar Rp.16.603.785.381.000,-, (enam belas triliun enam ratus tiga miliar tujuh ratus delapan puluh lima juta tiga ratus delapan puluh satu ribu rupiah) dan DAK Nonfisik sebesar Rp.6.617.200.000.000,-(enam triliun enam ratus tujuh belas miliar dua ratus juta rupiah).

Oleh karena itu diharapkan masyarakat mendapatkan pelayanan yang baik dari program pemerintah sebagai mana mestinya. Kebijakan adalah sebuah ketepan yang berlaku yang dicirikan kebijaka yang dikeluarkan oleh pemerintah adalah program prorakyat dan untuk mengatasi masalah rakyat dan memenuhi kepentingan rakyat.

Penyebab kematian ibu melahirkan adalah rendahnya kesadaran masyarakat tentang kesehatan ibu hamil terutama pada kaum perempuan ini salah satu menjadi faktor penentu angka kematian ibu dan bayi meskipun masih banyak faktor yang harus diperhatikan untuk menangani masalah ini, persoalan kematian yang terjadi lantaran indikasi yang lazim 
muncul yakni pendarahan, keracunanan kehamilan yang disertai kejang-kejang, aborsi dan infeksi.

Namun ternyata masih ada faktor lain yang juga cukup penting misalnya pemberdayaan perempuan yang tak begitu baik, latar belakang pendidikan, sosial ekonomi keluarga, lingkungan masyarakat, politik, kebijakan pemerintah juga sangat berpengaruh. kebijakan yang telah dikeluarkan oleh pemerintah, menuntut adanya keterlibatan masyarakat, demi terciptanya tujuan pembangunan yang telah di tetapkan begitu juga dengan pelaksanaan program jampersal yang merupakan program nasional bidang kesehatan yang dilaksanakan di seluruh Indonesia.

\section{METODE PENELITIAN}

Penelitian ini dilaksanakan kurang lebih selama dua bulan. Penelitian ini dilakukan di kabupaten polewali mandar yaitu di puskesmas pelitakan yang terletak di Jln. Poros tapango kecamatan tapango.

Disertai dengan pertimbangan bahwa melakukan penelitian mengenai program jaminana persalinan adalah untuk mengetahui bagaimana kinerja pemerintah dan dinas yang terkait dalam menjalankan program jampersal bagi IBU dan ANAK dan mengetahui sistem pelayanan yang telah ditetapkan apakah sudah berjalan dengan baik.

$$
\text { Jenis penelitian yang }
$$

digunakan dalam penelitian ini adalah kualitatif. Jumlah informan pada penelitian ini sebanyak 8 orang informan yaitu: kepala UPTD kesga, kepala puskesmas dan staf, pasien 3 orang, bidan 2 orang. Dalam penelitian pengumpulan data dilakukan melalui beberapa teknik yaitu wawancara mendalam, obserfasi dan dokumentasi. Untuk menjamin keabsahan data maka dilakukan pengumpulan data dengan mengunakan teknik triagulasi data, adalah teknik dengan memanfaatkan sesuatu yang alin diluar data untuk keperluan pengecekan atau perbandingan untuk data dengan metode wawancara mendalam untuk mendapatkan data dari informan dan mencocokkan dengan data informan yang lain. 
Dalam waktu yang tidak ditentukan sampai data yang diperoleh jenuh dan tidak ada lagi data yang baru pada tahap pelaksanaan peneliti akan melakukan proses pengumpulan data, klarifikasi data, analisis data, dan penarikan kesimpulan.

\section{HASIL DAN PEMBAHASAN}

Evaluasi Program Jampersal dalam perspektif alur proses/siklus kebijakan publik, menempati posisi terakhir setelah implementasi kebijakan, sehingga sudah sewajarnya jika kebijakan publik yang telah dibuat dan dilaksanakan lalu dievaluasi. Dari evaluasi akan diketahui keberhasilan atau kegagalan sebuah kebijakan, sehingga secara normatif akan diperoleh rekomendasi apakah kebijakan dapat dilanjutkan atau perlu perbaikan sebelum dilanjutkan, atau bahkan harus dihentikan.

Evaluasi juga menilai keterkaitan antara teori (kebijakan) dengan prakteknya dalam bentuk dampak kebijakan, apakah dampak tersebut sesuai dengan yang diperkirakan atau tidak. Dari hasil evaluasi pula kita dapat menilai apakah sebuah kebijakan program memberikan manfaat atau tidak bagi masyarakat yang dituju. Evaluasi kinerja pencapaian tujuan Kebijakan, yakni mengevaluasi kinerja orangorang yang bertanggung jawab mengimplementasikan kebijakan. Darinya kita akan memperoleh jawaban atau informasi mengenai kinerja implementasi, efektifitas dan efisiensi, yang terkait. Evaluasi kebijakan dan dampaknya, yakni mengevaluasi kebijakan itu sendiri serta kandungan programnya. Darinya kita akan memperoleh informasi mengenai manfaat (efek) kebijakan, dampak (outcome) kebijakan, kesesuaian kebijakan/program dengan tujuan yang ingin dicapainya (kesesuaian antara sarana dan tujuan). Sasaran Jaminan Persalinan adalah Ibu hamil, Ibu bersalin, Ibu nifas (pasca melahirkan sampai 42 hari), Bayi baru lahir (0-28 hari). Yang dapat memperoleh pelayanan jaminan persalinan adalah seluruh ibu hamil yang belum mempunyai jaminan kesehatan. 
Efektivitas Apakah hasil yang diinginkan telah tercapai dalam hal ini adalah Unit Pelayanan. Efektivitas merupakan hubungan antara output dengan tujuan, semakin besar kontribusi (sumbangan) output terhadap pencapaian tujuan, maka semakin efektif organisasi, program atau kegiatan.

Efektivitas berfokus pada hasil, program, atau kegiatan yang dinilai efektif apabila output yang dihasilkan dapat memenuhi tujuan yang diharapkan atau dikatakan spending wisely. Untuk lebih jelasnya dapat dilihat.

Membahas masalah ukuran efektivitas memang sangat bervariasi tergantung dari sudut terpenuhinya beberapa kriteria akhir.

Efektivitas merupakan suatu standar akan terpenuhinya mengenai sasaran dan tujuan yang akan dicapai serta menunjukan pada tingkat sejauhmana organisasi, program / kegiatan melaksanakan fungsifungsinya secara optimal.

Efesiensi Pelayanan akan efisien apabila birokrasi pelayanan dapat menyediakan input pelayanan, seperti biaya dan waktu pelayanan yang meringankan masyarakat pengguna jasa. Demikian pula pada sisi output pelayanan, birokrasi secara ideal harus dapat memberikan produk pelayanan yang berkualitas, terutama dari aspek biaya dan waktu pelayanan.

Program Jaminan Persalinan ditargetkan pada tahun 2020 mengurangi sampai $3 / 4$ resiko jumlah kematian Ibu dan Bayi, dan beberapa tahun terakhir telah menunjukkan perubahan yang tidak siknifikan penurunan dari waktu ke waktu sejak dilaksanakanya Program Jaminan Persalinan. Namun demikian pembangunan Millenium masih membutuhkan komitmen dan usaha kerja keras yang diberikan oleh lembaga pemerintahan sendiri adalah dimana ukuran berhasil tidaknya pencapaian tujuan organisasi tersebut dalam memberikan pelayanan kepada publik.

Berbicara masalah efesiensi yaitu jumlah usaha yang ditingkatkan untuk mencapai efektifitas. Pemerintah mengalokasikan Dana Khusus atau DAK sebesar 
Rp.23.220.985.381.000, terdiri dari DAK Fisik sebesar Rp.16.603.785.381.000 dan DAK Nonfisik Rp.6.617.200.000.000,-. Dari jumlah hitungan tersebut mustahil jika pelayanan program Jaminan persalinan tidak berjalan dengan baik.

Efisiensi adalah suatu kondisi atau keadaan, dimana penyelesaian suatu pekerjaan dilaksanakan dengan benar dan dengan penuh kemampuan yang dimiliki dan tanggun jawab yang besar kepada masyarakat umum.

Efisiensi mengangap bahwa tujuan-tujuan yang benar telah ditentukan dan berusaha untuk mencari cara-cara yang paling baik untuk mencapai tujuan-tujuan tersebut. Efisiensi dalam pendekatan ini beranggapan bahwa distribusi sumber daya yang diberikan adalah efisien apabila dan hanya bila terjadi distribusi sumber daya dengan cara realokasi yang dapat membuat setidaknya satu orang lebih baik sementara tidak meninggalkan orang lain lebih buruk. Situasi ini disebut sebagai Pareto optimal atau ketika hasil tertentu mustahil adalah untuk mencapai tanpa membuat setidaknya satu orang lebih buruk dalam situasi baru ini.

Kecukupan penyelenggaraan pelayanan publik harus memiliki standar pelayanan dan dipublikasikan sebagai jaminan adanya kepastian bagi penerima pelayanan. Standar pelayanan adalah ukuran yang diberlakukan dalam peyelenggaraan pelayanan yang wajib ditaati oleh pemberi dan atau penerima pelayanan. adapun standar pelayanan yakni meliputi sebagai berikut.

Prosedur pelayanan yang dilakukan bagi pemberi dan penerima pelayanan termasuk pegaduan.Waktu peyelesaian yang ditetapkan sejak saat pengajuan permohonan sampai dengan penyelesaian pelayanan termasuk pengaduan. Biaya pelayanan Biaya atau tarif pelayanan termasuk rincian yang ditetapkan dalam proses pemberian pelayanan.

Produk pelayanan Hasil pelayanan yang akan diterima sesuai dengan ketentuan yang telah ditetapkan. Sarana dan prasarana Penyedian sarana dan prasarana pelayanan yang memadai oleh 
penyelenggaraan pelayanan publik. Kompetensi petugas pemberi pelayanan. Kompetensi petugas pemberi pelayanan harus ditetapkan dengan tepat berdasarkan pengetahuan, keahlian, keterampilan, sikap, dan perilaku yang dibutuhkan.

Kecukupan berkenaan dengan seberapa jauh suatu tingkat efektivitas memuaskan kebutuhan, nilai atau kesempatan yang menumbuhkan adanya masalah. Kriteria kecukupan menekankan pada kuatnya hubungan antara alternatif kebijakan dan hasil yang diharapkan. Dengan kata lain kecukupan berarti biaya tetap dan efektivitas tetap. Melihat penjelasan dua kritria sebelumnya, yaitu efektivitas dan efisiensi, kecukupan program ini relatif baik. Hasil yang dicapai program ini belum sepenuhnya berhasil.

Kesamaan Perataan atau kesamaan erat hubungannya dengan konsepsi yang saling bersaing, yaitu keadilan atau kewajaran konflik etis sekitar dasar yang memadai untuk mendistribusikan sumber daya dalam masyarakat. Tujuan dari program ini adalah menurunkan AKI dan AKB serta pelayanan yang memuaskan. Atas dasar kesamaan dan pemerataan dalam tujuan penurunan AKI dan AKB dengan tujuan pembagunan kesehatan keluarga, program Jaminan Persalinan digratiskan untuk seluruh masyarakat umum baik kaya atau miskin Pegawai Negri Sipil atau Swasta tidak dibebankan biaya sepeserpun semua beban biaya ditangun oleh Negara dengan dialokasikanya DAK (Dana Alokasi Khusus dalam Program Jaminan Persalinan ini.

Kita ketahui syarat supaya bisa mengikuti program Jampersal adalah si Ibu hamil hanya memberikan foto copy KTP (maupun kartu identitas lainnya). Artinya tidak ada golongan khusus untuk penerima program ini, baik golongan masyarakat menengah kebawah maupun golongan masyarakat ke atas. Harapannya, begitu program disahkan seharusnya sudah dilakukan publikasi secara bertahap dan menyeluruh. Namun, pihak puskesmas tidak langsung melakukan publikasi secara merata.

Akibatnya, banyak masyarakat di wilayah kerja Puskesmas ini tidak 
mengetahui keberadaan program ini sejak awal tahun 2011. Namun, berbeda dengan perataan/kesamaan manfaat dari program Jampersal ini. Para peserta Jampersal di Puskesmas sudah menerima dan menikmati program ini melalui pelayanan yang diberikan pihak Puskemas.

Dapat ditarik kesimpulan bahwa pemerataan pelayanan Program Jampersal ini benar terjadi dan berjalan dengan baik tanpa diskriminasi atau membedakan dalam melakukan proses atau pelayanan kesehatan Jampersal ini dan pemerintah juga telah menjelasakan lewat peraturan mentri kesehatan bahwa pemerataan dalam pembangunan kesehatan. Tidak ada perbedaan pelayanan dan pendaftran dikalangan masyarakat.

$\begin{array}{rrrr}r & \text { Responsivitas } & \text { berkenaan } \\ \text { dengan } & \text { seberapa } & \text { jauh } & \text { suatu } \\ \text { kebijakan } & \text { dapat } & \text { memuaskan }\end{array}$
kebutuhan, preferensi atau nilai-nilai kelompok masyarakat tertentu. Responsivitas berbicara tentang apakah kriteria efektivitas, efisiensi, kecukupan dan kesamaan secara nyata mencerminkan kebutuhan, preferensi, dan nilai dari kelompok- kelompok tertentu. Responsivitas pada program Jampersal ini relatif baik. Dengan adanya kinerja birokrasi yang tinggi maka organisasi tersebut akan berjalan secara efektif, efisien dan responsif dalam memberikan pelayanan.

Pelayanan sangat erat hubungannya dengan kegiatan suatu lembaga baik pemerintah maupun swasta. Pelayanan merupakan salah satu fungsi dan bentuk tanggung jawab pemerintah kepada masyarakat.

Ketepatan secara dekat yang berhubungan dengan rasionalitas subtantif, karena pertanyaan tentang ketepatan kebijakan tidak berkenaan dengan suatu kriteria individu tetapi dua atau lebih kriteria secara bersama-sama ketepatan merujuk pada nilai atau tujuan-tujuan program dan kuatnya asumsi yang melandasi tujuan dalam sebuah kebijakan pablik melihat dari segi sasaran apakah sudah tepat sasarana dalam mengimplementasikan kebijakan jaminan persalinan tersebut dan apakah mencapai program untuk kepuasan publik. Dalam pelayanan pablik indikator 
yang ingin dicapai adalah kepuasan masyarakat dalam mendapatkan pelayanan oleh pemerintah yang terkait misalkan melakukan pelayanan secara adil tampa diskriminasi.

Mengukur efek suatu program/kebijakan pada kehidupan masyarakat dengan membandingkan kondisi antara sebelum dan sesudah adanya program tersebut. Mengukur efek menunjuk pada perlunya metodologi penelitian. Sedang membandingkan efek dengan tujuan mengharuskan penggunaan kriteria untuk mengukur keberhasilan Memperoleh informasi tentang kinerja. menilai kesesuaian dan perubahan program dengan rencana Memberikan umpan balik bagi manajemen dalam rangka perbaikan/ penyempurnaan.

Memberikan rekomendasi pada pembuat kebijakan untuk pembuatan keputusan lebih lanjut mengenai program di masa mendatang. Evaluasi kinerja pencapaian tujuan Kebijakan, yakni mengevaluasi kinerja orang-orang yang bertanggung jawab mengimplementasikan kebijakan.
Faktor

Penghambat Jampersal Program Jampersal dapat difahami sebagai akomodasi kepentingan masyarakat dalam kebijakan serta adanya partisipasi masyarakat dalam proses pembuatan kebijakan publik

Penyediaan sarana dan Prasarana Sarana kesehatan merupakan salah satu faktor penting yang mendukung berlangsungnya sistem pelayanan kesehatan. Puskesmas sebagai penyedia pelayanan kesehatan kepada masyarakat ditutut untuk bertanggung jawab terhadap keandalan, keakurasian, dan keamanan sarana dan prasarana yang digunakan. Sesuai perkembangannya maka pengelolaan mutu fasilitas sarana dan prasarana menjadi sangat penting. Sarana pelayanan kesehatan dasar telah.

Angaran yang di alokasikan oleh pemerintah diBidang Kesehatan sebesar Rp.23.220.985.381.000,(dua puluh tiga triliun dua ratus dua 9 puluh miliar sembilan ratus delapan puluh lima juta tiga ratus delapan puluh satu ribu rupiah) terdiri dari DAK Fisik sebesar Rp.16.603.785.381.000,-, (enam 
belas triliun enam ratus tiga miliar tujuh ratus delapan puluh lima juta tiga ratus delapan puluh satu ribu rupiah) dan DAK Nonfisik sebesar Rp.6.617.200.000.000,-(enam triliun enam ratus tujuh belas miliar dua ratus juta rupiah). Mustahil rasanya jika Program kemanusian tidak berjalan dengan sesuai tujuan Program jampersal yaitu penekanan AKB dan AKI.

Fasilitas pendukung pelayanan di Puskesmas pelitakan juga belum cukup memadai, misalnya fasilitas parkir pasien, ruang tunggu yang nyaman, pencahayaan ruangan yang cukup, dll.

Komunikasi yang kurang Selama ini banyak kebijakan Pemerintah yang dikeluhkan oleh masyarakat karena dianggap tidak menyentuh langsung kepentingan masyarakat atau tidak memberikan manfaat yang sangat dibutuhkan oleh masyarakat luas, terutama pada masyarakat miskin. Tetapi ternyata di antara banyak kebijakan Pemerintah. Penulis menemukan bahwa Jaminan Persalinan (JamPersal) yang di luncurkan pada tahun 2011 melalui Kementerian Kesehatan, merupakan kebijakan yang sangat membantu masyarakat tidak mampu.

Jampersal mungkin salah satu contoh best practice dari sedikit kebijakan pemerintah yang dianggap baik terutama dikaitkan dengan pelayanan publik. Tapi sering terjadi diskomunikasi antara pemerintah dan masyarakat yang sering kali tidak memahami bagaimana proses dan prosedur yang baik dalam Program Jampersal. banyak yang mengeluhkan program Jampersal ini di kalangan masyarakat terutama dalam proses pelayanan ini dikarenakan adanya komunikasi pemerintah yang tidak difahami oleh penguna Program Jampersal. Ini dikarenakan masyarakat juga perlu mendapatkan arahan dari pemerintah sector setempat seperti, camat, desa dan lurah diharapkan untuk mensosialisasikan, ini dikarenakan masih banyak masyarakat yang belum mengetahui apa itu masa nifas prosedur pelayanannya. 


\section{KESIMPULAN}

Evaluasi Program Jaminan Persalinan adalah program pemerintah penekanan AKI dan AKB dan peningkatan derajat kesehatan keluarga. Untuk mengukur seberapah jauh program Jampersal ini bermanfaat bagi masyarakat maka dilihat dari beberapa aspek antara lain, Efektifitas, Efesiensi, Kecukupan, Kesamaan, Responsifitas dan Ketepatan berdasarkan hasil penelitian menunjukkan keenam aspek tersebut tidak tercapai dalam Program Jampersal bahkan aspek responsivitas dan kesamaan tidak tercapai sama sekali. Program yang diukur adalah, pelayanan pemeriksaan ibu hamil, pelayanan persalinan, pelayanan Nifas dan pelayanan bayi bari lahir, yang menjadi sorotang penelitian ini bukan pada pelayanan tapi sampai dimana pemerintah memaksimalkan Program Jampersal untuk kepentingan Publik. angaran sebesar Rp. 23. 220. 985. 381. 000 terdiri dari DAK Fisik sebesar Rp.16.603.785.381.000,-, dan DAK Nonfisik Rp.6.617.200.000.000. Dari hasil penelitian besar angaran tersebut tidak mempengaruhi Program Jampersal menjadi lebih baik.Faktor Penghambat Jampersal. Dari hasil penelitian yang didapatkan dilapangan dan informasi dari informan sebagai penulis dapat saya simpulkan bahwa kegagalan pencapaian Program Jampersal berada pada pengeloaan yang tidak tepat terjadi komunikasi yang tidak baik antara rakyat dan pemerintah dibuktikan dengan masih banyak yang tidak memahami proses program jampersal yang baik bahkan dari sebesar Rp.23.220.985.381.000 terdiri dari DAK Fisik sebesar Rp.16.603.785.381.000,-, dan DAK Nonfisik Rp.6.617.200.000.000. tidak dapat mengubah Program Jampersal menjadi lebih baik bahkan ada salah satu program yang dapat dikategorikan tidak tercapai yaitu responsivitas dari pelayanan Nifas dikarenakan sosialisasi tidak berjalan baik dalam hal ini komunikasi pemerintah dan rakyat tidak tercapai.

\section{DAFTAR PUSTAKA}

Arikunto,S. 2002. Prosedur penelitian: suatu pendekatan 
praktik, Edisi, Revisi V.

Yogyakarta: Rineka cipta.

Abidin, Said Zainal. 2004.

Kebijakan publik. Jakarta:

Pancur Siwah.

Agustino, Leo. 2006. Dasar dasar kebijakan publik. Bandung: Alfabeta.

Dwiyanto, Agus. 2005. Mewujudkan good governance melalui pelayanan publik. Yogyakarta: Gajamadah University Pres.

Ekowati, Mas Roro Lilik. 2005. Perencanaan, implementasi,dan evaluasi kebiakan atau program. Surakarta: Pustaka Cakra.

Islamy. M Irfan. 1984. PrinsipPrinsip Perumusan Kebijaksanaan Negara. Malang: Bumi Aksara.

Mustari. Nuryanti. 2013. Implementasi Kebijakan Publik. Makassar: Membumi Publishing.

Musrari. Nuryanti, 2015. Pemahaman Kebijakan Publik formulasi, Iplementasi, dan Evaluasi Kebijakan Publik. Yogyakarta: LeutikaPrio.

Sugiono. 2010. Metode Penelitian, Kuantitatif, Kualitatif, dan $R \& D$. Bandung: Alfabeta.

Mukarom. Zaenal. Dkk. 2015. Manajemen Pelayanan Publik. Bandung: CV Pustaka Setia 